\title{
Translational and structural analysis of the shortest legume ENOD40 gene in Lupinus luteus
}

\author{
Jan Podkowinski ${ }^{1 凶}$, Agnieszka Zmienko ${ }^{1}$, Blazena Florek ${ }^{1}$, Pawel Wojciechowski², \\ Agnieszka Rybarczyk ${ }^{1}$, Jan Wrzesinski ${ }^{1}$, Jerzy Ciesiolka ${ }^{1}$, Jacek Blazewicz ${ }^{1}$, \\ Adam Kondorosi ${ }^{3}$, Martin Crespi ${ }^{3}$ and Andrzej Legocki ${ }^{1}$ \\ ${ }^{1}$ Institute of Bioorganic Chemistry, Polish Academy of Sciences, Poznań, Poland; ${ }^{2}$ Institute of Computing \\ Science, Poznan University of Technology, Poznań, Poland; ${ }^{3}$ Institut des Sciences du Vegetal, Gif sur Yvette, \\ Cedex, France
}

Received: 02 October, 2008; revised: 04 February, 2009; accepted: 06 March, 2009 available on-line: 14 March, 2009

\begin{abstract}
Two early nodulin 40 (enod40) genes, ENOD40-1, the shortest legume ENOD40 gene, and ENOD40-2, were isolated from Lupinus luteus, a legume with indeterminate nodules. Both genes were expressed at similar levels during symbiosis with nitrogen-fixing bacteria. ENOD40 phylogeny clustered the L. luteus genes with legumes forming determinate nodules and revealed peptide similarities. The ENOD40-1 small ORF A fused to a reporter gene was efficiently expressed in plant cells, indicating that the start codon is recognized for translation. The ENOD40-1 RNA structure predicted based on $\mathrm{Pb}$ (II)-induced cleavage and modeling revealed four structurally conserved domains, an absence of domain 4 characteristic for legumes of indeterminate nodules, and interactions between the conserved region I and a region located upstream of domain 6 . Domain 2 contains $\mathrm{Mg}(\mathrm{II})$ ion binding sites essential for organizing RNA secondary structure. The differences between L. luteus and Glycine max ENOD40 RNA models suggest the possibility of a switch between two structural states of ENOD40 transcript.
\end{abstract}

Keywords: ENOD40, nitrogen fixation, phylogeny, transcript structure

\section{INTRODUCTION}

ENOD40 genes exhibit several intriguing structural features, such as the absence of a long conserved ORF, the presence of two small conserved ORFs, and regions corresponding to conserved secondary structures of the transcript. Due to its high expression during symbiotic nitrogen fixation, this gene is intensively studied in legumes. ENOD40 is also present in plants from the Poaceae and Solanaceae families (Kouchi et al., 1999; Compaan et al., 2003; Larsen, 2003; Vleghels et al., 2003). Moreover, a recent search for RNA domains of secondary structures similar to ENOD40 domains identified a number of ENOD40-like genes from diverse angiosperm families, including Brassicaceae (Gultyaev \& Roussis, 2007).

The mechanism of ENOD40 gene activity seems to be of a dual mode: one relying on the encoded short peptide(s) and the second depending on the transcript structure. A comparison of Papilionoideae ENOD40 genes has revealed two conserved regions, I and II, located within the $5^{\prime}$ end and the central part of the cDNA, respectively, and up to six domains of conserved RNA secondary structure (Gultyaev \& Roussis, 2007). The legume ENOD40

\footnotetext{
${ }^{\square}$ Corresponding author: Jan Podkowinski, Institute of Bioorganic Chemistry, Polish Academy of Sciences, Z. Noskowskiego 12/14, 61-704 Poznań, Poland; phone: (48) 618528503 ext. 148; fax: (48) 61852 0532, e-mail: jpodkow@ibch.poznan.pl Accession numbers: L. luteus early nodulin (ENOD40-1) mRNA, AF352375; L. luteus early nodulin (ENOD40-1) gene, AF352372; L. luteus ENOD40-2 mRNA, AF352374; L. luteus ENOD40-2 gene, AF352373.

Abbreviations: CaMV, cauliflower mosaic virus; DPI, days post infection; ENOD, early nodulin; GUS, beta-glucuronidase reporter gene; NOS, nopaline synthase; ORF, open reading frame; PCR, polymerase chain reaction; pfu, plaque forming units; SORF, small open reading frames coding for peptides shorter than 100 amino acids; UTR, untranslated region.
} 
genes do not contain conserved coding sequences except for two short ORFs, ORF A and ORF B, that encode small peptides. ORF A of 10-13 codons is located in the conserved region I and partially overlaps ORF B. The growing evidence of the role of plant short peptides supports the hypothesis that either the single ENOD40 peptide A or both $\mathrm{A}$ and $B$ peptides may have biological functions (Barciszewski \& Legocki, 1997; Linsey, 2001; Wen et al., 2004). Both ENOD40 ORFs match the novel class of genetic elements - sORS (short open reading frames coding for peptides shorter than 100 amino acids). ORF A translation was demonstrated for Medicago truncatula (Sousa et al., 2001) and Glycine max ENOD40, in which the synthesis of both ORF A and ORF B peptides was proven in vitro (Rohrig et al., 2002). The G. max ORF A and ORF B peptides were found to interact with sucrose synthase (Rohrig et al., 2002) and the ORF A peptide covalently bound to cystein 264 of sucrose synthase increased the enzyme cleavage activity (the enzyme could function in both sucrose synthesis and degradation) (Rohrig et al., 2004). ORF A and ORF B peptides antagonize Zea mays sucrose synthase phosphorylation decreasing the efficiency of the enzyme's proteolysis (Hardin et al., 2003). This competition between ENOD40 peptides and plant-specific calcium-dependent kinase, an enzyme involved in regulation of diverse cellular processes (Klimecka \& Muszynska, 2007), points to an ENOD40 regulatory function. In addition to the above in vitro data, ENOD40 peptide A activity was also confirmed in Arabidopsis thaliana, where it inhibited expansion of protoplasts similarly to overexpression of the full-length ENOD40 gene (Guzzo et al., 2005).

The interactions between sucrose synthase and ENOD40 peptides A and B suggest a role for these peptides in photosynthate accumulation in sink regions and are congruent with their expression pattern. The activity of the ENOD40 genes is associated with new organ formation with high expression observed during the development of the nodule, an organ specific for symbiotic nitrogen fixation (Asad et al., 1994; Crespi et al., 1994; Minami et al., 1996; Fang \& Hirsch, 1998; Wan et al., 2007; Kumagai et al., 2006; Murakami et al., 2006). The gene is expressed also in mature nodules, meristems and cells of high mitotic or dedifferentiation activity (Kouchi \& Hata, 1993; Yang et al., 1993; Matvienko et al., 1994; Vijn et al., 1995; Papadopoulou et al., 1996). Transgenic plants with silenced or overexpressed ENOD40 gene provide evidence on a direct relationship between the gene expression and nodule formation efficiency (Charon et al., 1997; 1999; Wan et al., 2007).

ENOD40 expression not related to symbiotic interactions is associated with new organ initiation and developmental processes, such as formation of lateral roots and shoots (Papadopoulou et al., 1996; Varkonyi-Gasic \& White, 2002). In the non-legume plant Oryza sativa, ENOD40 expression is observed in young, lateral vascular bundles prior to the onset of leaf expansion (Kouchi et al., 1999). Recently, an $E N O D 40$ function in cell elongation and cross-talk with ethylene signaling was demonstrated in a Nicotiana tabacum cell suspension (Ruttink et al., 2006), A. thaliana (Guzzo et al., 2005) and rice (Dey et al., 2004).

Apart from the biological activity of the SORFs, the ENOD40 gene has been proposed to be active at the RNA level based on the GC content and free energy of the transcript folding similar to those of noncoding RNAs (Crespi et al., 1994; Sousa et al., 2001). The finding that the putative RNA structural elements of ENOD40-like genes are more conserved than the peptide sequence suggests that the general function(s) of the genes might be determined by the RNA (Gultyaev \& Roussis, 2007). This hypothesis is supported by ENOD40 mRNA interactions with the nuclear RNA-binding protein MtRBP1 (Campalans et al., 2004). The interactions are independent of ORF A translation and result in the relocalization of the ENOD40 RNA-MtRBP1 complex into the cytoplasm.

To elucidate the molecular mechanism of ENOD40 activity, the G. max ENOD40-1 transcript secondary structure was studied (Girard et al., 2003). A phylogenetic analysis and modeling of RNA folding identified six domains, named domains 1-6, of conserved secondary structure which was confirmed experimentally.

The function of the domains is not elucidated but numerous data point to their importance. The presence of domains 1,2 and 3 in ENOD40 genes from Poaceae and Solanaceae families suggests that their function is not limited to symbiotic nitrogen fixation (Gultyaev \& Roussis, 2007). The conserved domain 1 is located in a region of biological activity in M. truncatula ENOD40 mRNA (Sousa et al., 2001). Domain 4, specific for legume plants with indeterminate nodules, is proposed to be involved in the determination of nodule type (Girard et al., 2003).

In this study, we analyzed Lupinus luteus L. ENOD40 genes, including one coding for the shortest legume ENOD40 transcript. L. luteus is not only phylogenetically distant from the intensively studied legume plants such as Medicago truncatula, Lotus japonicus and Glycine max, but also exhibits peculiarities in symbiotic nodule development. The Lupinus nodule meristem is active along nodule ontogeny (persistent), a trait of indeterminate nodulation, but nodules originate from outer cortex cells, which normally form determinate nodules (characterized by non-persistent meristems). Furthermore, bacteria enter nodule primordia without infection threads and meristematic cells are infected with bacteria (Lo- 
tocka et al., 2000; González-Sama et al., 2004; Strozycki et al., 2007). A comparison of L. luteus ENOD40 expression patterns, genes and transcript structures with those of model legume plants, including $M$. truncatula of indeterminate nodule type and plants of determinate nodules, such as L. japonicus and G. max, may shed light on ENOD40 transcript structure-function relationships in nodulation.

\section{MATERIALS AND METHODS}

Plant growing and harvesting. Lupinus luteus L. var. Ventus was grown in 21 pots with perlite under $16 \mathrm{~h}$ day at $23^{\circ} \mathrm{C}$. Seed sterilization, seeding and broth composition were according to Strozycki et al. (2003). Plants grown under symbiotic conditions were infected with $10 \mathrm{ml}$ of 7-day old Bradyrhizobium sp. (Lupinus) WM9 culture (YMB broth; Vincent, 1970) at $\mathrm{OD}_{500}=1.287\left(1.2 \times 10^{9} \mathrm{cfu} / \mathrm{ml}\right)$ days after seeding (4leaf plants), and nitrate was excluded from the broth. The root sector $2 \mathrm{~cm}$ below the hypocotyl and $2 \mathrm{~cm}$ above the root tip was collected for early stages of symbiosis. The plant material was frozen in liquid nitrogen within 2 min after harvesting.

dsDNA probe labeling. Double stranded cDNA (100 ng) was ${ }^{32}$ P-labeled with the HexaLabel kit (Fermentas) according to the manufacturer's protocol with the incubation at $37^{\circ} \mathrm{C}$ extended to $30 \mathrm{~min}$. The final product was purified with the QIAquick PCR purification kit (QIAgen).

Hybridization. Hybond $\mathrm{N}^{+}$membrane (Amersham) was used for library screening and Southern and Northern hybridizations. The nucleic acids transfer followed by fixation at $80^{\circ} \mathrm{C}$ for $2 \mathrm{~h}$ was according to the producer's protocol. The hybridization in solution composed of $5 \times$ SSC, $5 \times$ Denhardt, $0.5 \%$ SDS was as suggested in Hybond $\mathrm{N}^{+}$protocol. The results were read with a Typhoon 8600 phosphoimager and analyzed with ImageQuant software.

Genomic library screening. The L. luteus var. Ventus genomic library (EMBL3 vector, average insert length $15 \mathrm{~kb}$ ) was screened with a fragment of $M$. truncatula ENOD40 cDNA as a probe at $55^{\circ} \mathrm{C}$ according to the protocol by Stratagene. A total of $4 \times 10^{5}$ plaque forming units was screened on plates seeded at $260 \mathrm{pfu} / \mathrm{cm}^{2}$.

cDNA library screening and cDNA clone isolation. The L. luteus var. Ventus cDNA library (UniZAP XR vector, Stratagene; average insert length $1.8 \mathrm{~kb})$ prepared from roots during symbiosis with Bradyrhizobium sp. at 7, 14, and 21 days post infection (DPI) was screened with ENOD40-1 as a probe at $65^{\circ} \mathrm{C}$ according to the protocol by Stratagene. A total of $4 \times 10^{5} p f u$ was screened on plates seeded at $260 \mathrm{pfu} / \mathrm{cm}^{2}$.
Southern hybridization. Five microgram of genomic DNA digested with EcoRV and HindIII (Fermentas) was separated on a $0.7 \%$ agarose gel and transferred to Hybond $\mathrm{N}^{+}$. The hybridization was carried out at $68^{\circ} \mathrm{C}$. The dsDNA probe was PCR-amplified with Taq DNA polymerase (Fermentas), pSK Bluescript targeted primers JP203 CGGCCAGTGAATTGTAATACG and JP204 ATGACCATGATTACGCCAAGC, and $1 \mathrm{ng}$ of cDNA cloned in pSK Bluescript as a template. The PCR product was purified with the QIAquick PCR Purification Kit (QIAGEN).

Northern hybridization. RNA was isolated from frozen plant material according to Logemann et al. (1987). Formaldehyde/agarose gel electrophoresis (Sambrok \& Russell, 2002) was used to analyze up to $5 \mu \mathrm{g}$ of RNA per lane. The gel was either stained in $0.5 \mu \mathrm{g} / \mathrm{ml}$ ethidium bromide for RNA visualization or processed to transfer RNA on Hybond $\mathrm{N}^{+}$ which was then hybridized at $68^{\circ} \mathrm{C}$ using the same procedures as for Southern hybridization.

Semi-quantitative RT-PCR analysis of ENOD40 gene expression. First strand cDNA was synthesized with $1 \mu \mathrm{g}$ of total RNA as a template, oligo (dT) primer and RevertAid M-MuLV Reverse Transcriptase (Fermentas) according to the producer's protocol. One microliter of the reverse transcription reaction was used as a template for PCR amplification with $1 \mathrm{U}$ Taq DNA polymerase (Fermentas) in a final volume of $40 \mu \mathrm{l}$; the amplification reaction contained $1.6 \mathrm{mM} \mathrm{MgCl}, 0.2 \mathrm{mM}$ dNTP, $0.4 \mu \mathrm{M}$ forward primer, $0.4 \mu \mathrm{M}$ reverse primer, and $1 \times$ Taq buffer (Fermentas). The primers for ENOD40-1 amplification were JP4-05 AGAGACTGTTTATAATATTAACTG and JP4-06 GATATGCATACAAAAAACATTC; the primers for ENOD40-2 were JP4-07 CTCATAACTCATAAGGGCATAA and JP4-08 GGGATAGCATACATAGTATTAA. The amplification program was one cycle at $94^{\circ} \mathrm{C}$ for $1 \mathrm{~min}$, three cycles of $94^{\circ} \mathrm{C}$ for $40 \mathrm{~s}, 53^{\circ} \mathrm{C}$ for $1 \mathrm{~min}$, and $72^{\circ} \mathrm{C}$ for 1 min, followed by 21 cycles of $94^{\circ} \mathrm{C}$ for $40 \mathrm{~s}, 51^{\circ} \mathrm{C}$ for $1 \mathrm{~min}$, and $72^{\circ} \mathrm{C}$ for $1 \mathrm{~min}$, and a final extension at $72^{\circ} \mathrm{C}$ for $5 \mathrm{~min}$. A $10 \mu \mathrm{l}$ aliquot of the reaction was analyzed on a $0.7 \%$ agarose gel stained in $0.5 \mu \mathrm{g} / \mathrm{ml}$ ethidium bromide after electrophoresis. The gel was scanned with Typhoon 8600 and ImageQuant software was used for quantitative analysis.

Analysis of translational efficiency of selected ORFs by transient expression. Constructs for analysis of translation efficiency of ENOD40-1 ORFs were generated in the pSK Bluescript vector which contained the CaMV $35 S$ promoter, GUS coding sequence (uidA gene) and NOS terminator from pBI121. Restriction enzyme digestion (PstI, BstXI, EcoRI, BamHI, XbaI), dephosphorylation and ligation were performed according to Fermentas. Pwo DNA polymerase (Promega) was used for DNA amplification and blunt-ending. 
The construct pTE20 comprised the CaMV promoter, GUS coding sequence without the starting codon, and NOS terminator. The remodeled spacer between the CaMV promoter and ATG-less GUS coding sequence containing a BamHI and an $\mathrm{XbaI}$ site proximal and distal to the CaMV promoter, respectively, allowed the directional insertion of the ENOD40-1 cDNA fragment.

The pTE30 construct contained the CaMV 35S promoter followed by the $5^{\prime}$ UTR and a fusion of ORF A and the ATG-less GUS coding sequence.

The 1-86 bp fragment of L. luteus ENOD40-1 cDNA was amplified with the forward primer te01 ATGGATCCTGGAAATTCTCCAAAACCA (ENOD40-1 non-specific region in bold, BamHI site underlined) and reverse primer te02 ATTCTAGAACCATGGATGGATTTTTGC (ENOD40-1 non-specific region in bold, $\mathrm{XbaI}$ site underlined), and cloned into the BamHI and XbaI sites of pTE20 to generate the pTE30 construct.

The pTE32 construct contained the CaMV 35S promoter followed by ORF A without the 5' UTR, and the ATG-less GUS.

The ENOD40-1 ORF A 51-86 bp fragment was amplified with the forward primer te09 ATGGATCCATGGAACTCTCTTGGCAA (ENOD40-1 non-specific region in bold, BamHI site underlined) and the reverse primer te 02 , and cloned into the $\mathrm{BamHI}$ and $\mathrm{XbaI}$ sites of pTE20, to generate the pTE32 construct.

The pTE40 construct contained the CaMV 35S promoter followed by ORF B with its complete upstream region and ATG-less GUS.

The 1-90 bp fragment of ENOD40-1 was amplified with the forward primer te 01 and reverse primer te03 ATTCTAGATTCAAGAACCATG-GATGGA (ENOD40-1 non-specific part in bold, XbaI site underlined), and cloned into BamHI and XbaI sites of pTE20 to produce the pTE40 construct.

The pTE50 construct contained the CaMV 35S promoter followed by the ENOD40-1 cDNA region 1-229 bp, ORF 330 (named according to the position of starting codon), and ATG-less GUS.

The 1-404 bp fragment of ENOD40-1 cDNA, containing the ORF 330 and its upstream region, was amplified as above with the forward primer te 01 and reverse primer te04 ATTCTAGACATACATTCTACTGCAACA (ENOD40-1 non-specific region in bold, XbaI site underlined), and cloned into the BamHI and XbaI sites of pTE20 to generate pTE50. The ORF 330-329 bp long upstream region included ORF A and ORF B.

Preparation of tungsten beads coated with DNA. Tungsten beads $(15 \mathrm{mg})$ washed with $0.1 \mathrm{~N}$ nitric acid, deionized water and $96 \%$ ethanol were suspended in $1.0 \mathrm{ml}$ of deionized water. A total of $150 \mu \mathrm{l}$ of the suspension was combined with $30 \mu \mathrm{l}$ of the construct ( $1 \mu \mathrm{g} / \mu \mathrm{l}$ DNA concentration), vortexed and mixed. The DNA coated beads were combined with $150 \mu \mathrm{l}$ of $2.5 \mathrm{M}$ calcium chloride, vortexed, supplemented with $60 \mu \mathrm{l}$ of $0.1 \mathrm{M}$ spermidine and vortexed again for $5 \mathrm{~min}$. The DNA coated tungsten beads were spun down, washed with $96 \%$ ethanol and resuspended in $180 \mu \mathrm{l}$ of $96 \%$ ethanol.

Plant transformation by leaf bombardment. Nicotiana tabacum leaves (grown in vitro) were bombarded with $10 \mu \mathrm{l}$ of the DNA-coated tungsten beads using $0.5 \mathrm{MPa}$ of helium at a $5 \mathrm{~cm}$ distance between the cartridge and the leaves, two shots per leaf. The leaves were grown for two more days and then stained in a solution of $1 \mathrm{mM} \mathrm{X}$-GlcA (5-bromo-4-chloro-3-indolyl $\beta$-D-glucuronide cyclohexylammonium salt, Sigma), $0.1 \mathrm{M} \mathrm{Na}_{2} \mathrm{HPO}_{4}, 0.1 \mathrm{M}$ $\mathrm{NaH}_{2} \mathrm{PO}_{4}, 0.01 \mathrm{M}$ EDTA, $0.5 \mathrm{mM} \mathrm{K}_{4} \mathrm{Fe}(\mathrm{CN})_{6}, 0.5 \mathrm{mM}$ $\mathrm{K}_{3} \mathrm{Fe}(\mathrm{CN})_{6^{\prime}}$ and $0.1 \%$ Triton $\mathrm{X}-100$ for $24 \mathrm{~h}$ at $37^{\circ} \mathrm{C}$. Following the staining, the leaves were washed with $50 \%$ and $96 \%$ ethanol.

\section{Probing RNA structure with $\mathrm{Pb}(\mathrm{II})$-induced cleavage}

T7 RNA polymerase template and RNA synthesis. The ENOD40-1 cDNA was cloned in pSK Bluescript with the $5^{\prime}$ end proximal to the T7 RNA polymerase promoter and the $3^{\prime}$ end at the XbaI site to produce the pHG2 construct. The $8 \mathrm{bp}$ spacer ATTA CGAG separated the T7 RNA polymerase promoter from the $5^{\prime}$ end of the insert. Two micrograms of linearized pHG2 DNA (XbaI digestion followed by proteinase $\mathrm{K}$ treatment and QIAquick PCR purification) was used as a template for RNA synthesis with the T7 RNA polymerase (Fermentas). The reaction was composed of $0.3 \mathrm{U} / \mu \mathrm{l}$ of T7 RNA polymerase, $2 \mathrm{mM} \mathrm{NTP}$, and 0.5-1.25 U/ $\mu$ ribonuclease inhibitor (Fermentas), incubated for $3 \mathrm{~h}$ at $37^{\circ} \mathrm{C}$, and stopped with EDTA pH 8.0, which was added to a final concentration of $20 \mathrm{mM}$. RNA was precipitated with ethanol and dissolved in water. The analyzed RNA lacked the poly A tail, as T7 RNA polymerase often produces populations of truncated molecules on a template with a homo-polymeric region at the end.

$\mathrm{Pb}$ (II)-induced cleavage and primer extension by reverse transcriptase. RNA concentration was evaluated measuring absorbance (with spectrophotometer or phosphorimager Typhoon); low RNA concentrations mentioned below were obtained as dilutions from samples of higher concentration. ENOD40-1 RNA $(0.8 \mu \mathrm{M})$ was supplemented with carrier tRNA to a total RNA concentration of $4 \mu \mathrm{M}$, incubated at $65^{\circ} \mathrm{C}$ for $3 \mathrm{~min}$ in the $2 \times$ reaction buffer, and cooled to $25^{\circ} \mathrm{C}$. An equal volume of lead(II) acetate solution of two times higher concentration than the final concentration was added and the reaction was performed in the mixture composed of (final concentrations is given for all com- 
ponents) $10 \mathrm{mM}$ Tris/HCl, $\mathrm{pH} 7.2,40 \mathrm{mM} \mathrm{NaCl}$, $10 \mathrm{mM} \mathrm{MgCl}{ }_{2}, 0.4 \mu \mathrm{M}$ of ENOD40-1 RNA, $1.6 \mu \mathrm{M}$ of carrier tRNA and $0.0 \mathrm{mM}, 0.5 \mathrm{mM}, 1 \mathrm{mM}$ or 2 $\mathrm{mM} \mathrm{Pb}(\mathrm{II})$ ions. The $\mathrm{Pb}$ (II)-induced cleavage reactions were performed with increasing concentrations of $\mathrm{Pb}$ (II) ions to saturate all possible $\mathrm{Pb}$ (II) binding sites. The reaction mixture was incubated at $25^{\circ} \mathrm{C}$ for $10 \mathrm{~min}$, stopped with EDTA added to a final concentration of $5 \mathrm{mM}$, precipitated with ethanol and dissolved in water. The primer extension reaction used to determine positions of $\mathrm{Pb}$ (II)-induced breaks was carried out $30 \mathrm{~min}$ at $42^{\circ} \mathrm{C}$ in a final volume of $10 \mu \mathrm{l}$ in $50 \mathrm{mM}$ Tris/ $\mathrm{HCl}, \mathrm{pH} 8.3,75 \mathrm{mM} \mathrm{KCl}, 10$ mM DTT, $3 \mathrm{mM} \mathrm{MgCl}{ }_{2}, 1 \mathrm{mM}$ dNTP, $50 \mathrm{U}$ M-MLV (Promega), $1 \mu \mathrm{M}{ }^{32} \mathrm{P} 5^{\prime}$ end labeled reverse transcription primer (see below), usually $2-5 \times 10^{5}$ c.p.m. ${ }^{32} \mathrm{P}$, and $1.0 \mu \mathrm{M}$ of total cleaved RNA (total RNA is composed of ENOD40 transcript and carrier tRNA). The reaction was stopped with an equal volume of $7 \mathrm{M}$ urea, $20 \mathrm{mM}$ EDTA. Sequencing reactions were carried out in parallel to facilitate interpretation of the primer extension results; in each of the four sequencing reactions, one of the dideoxynucleotides was added to a final concentration of $0.025 \mathrm{mM}$ and the other components of the reactions were as above. The reverse transcription primers were as follows: RT-1 ATGCGTGCTTATTCAAGAAC, RT-2 TGGTGATTAGAGAAGCCAATA, RT-3 TGGAGTCCAAGCCTTTTTGTG, RT-4 GTAACATCTCAAAGGAGTGC and RT-5 ATACAAAGAGACTGTTTATAATAT-TAACTG. The last 24 nucleotides at the 3' end of the ENOD40-1 transcript were not accessible for the analysis due to interaction with the reverse transcriptase primer. The cleavage sites were detected by separating the products of the reverse transcriptase primer extension reaction on a gel along with the products of dideoxy sequencing reactions. The electrophoresis was run on $12 \%$ polyacrylamide, $7 \mathrm{M}$ urea, $1 \times \mathrm{TBE}$.

RNA structure modeling. ENOD40-1 RNA structure prediction was performed with the Zucker/Turner mfold program version 3.1 (Zucker, 2003; http://www.bioinfo.rpi.edu/applications/mfold/). The standard default parameters were used during the modeling, with the exception of forcing domain 1 (nt 109-137), domain 2 (nt 153-288), domain 3 (nt 310-327) and domain 6 (nt 440-497) to form the structures proposed by Girard et al. (2003). Models were validated with the following data: $\mathrm{Pb}$ (II)-induced cleavage of LIENOD40-1 transcript (see above), LIENOD40-1 regions corresponding to G. max ENOD40-1 single stranded regions (26-31), (78-84), (332-337) and (355-336) (Girard et al., 2003), and pairing between ENOD40 conserved regions.

Phylogenetic analysis. Phylogenetic analyses were conducted in MEGA4 (Tamura et al., 2007). The accession numbers of the 23 analyzed ENOD40 sequences, including L. luteus ENOD40-1 and ENOD40-2, are given in Table 1. G. max ENOD402 (X86442) fragment 1744-2960 bp and L. japonicus ENOD40 (AF013594) fragment 792-1561 bp were taken for analysis, while the rest of the sequences were used without trimming. The ENOD40 evolutionary history was inferred using the NeighborJoining method (Saitou \& Nei, 1987), and the optimal tree was generated with a bootstrap test using 500 replicates (Felsenstein, 1981). The evolutionary distances were computed using the Maximum Composite Likelihood method. Codon positions included were $1 s t+2 n d+3 r d+N o n c o d i n g$. All positions containing gaps and missing data were eliminated from the dataset (complete deletion option). There were a total of 183 positions in the final dataset.

\section{RESULTS}

Two ENOD40 genes are present in the L. luteus genome and contain a 10-nt promoter-proximal region conserved in Papilionoideae and Poaceae

We screened a L. luteus genomic library and isolated two genomic clones containing ENOD40 genes and their promoter regions, which we named ENOD401 (AF352372.1) and ENOD40-2 (AF352373.1). Moreover, screening cDNA library resulted in six cDNA clones - four of them represented ENOD40-1 (AF352375), the shortest legume ENOD40 gene, and two others represented ENOD40-2 (AF352374). The L. luteus ENOD40 cDNAs are $85 \%$ identical to one another and possess two conserved regions, I and II. The conserved region I contains ORF A encoding a 12 amino-acid peptide (MELSWQKSIHGS in ENOD40-1 and MKLFWQKSINGS in ENOD40-2) and the first three codons of the extremely short ORF $\mathrm{B}$, which is composed of four (ENOD40-1) or five (ENOD40-2) codons.

Promoter analysis revealed a unique $90 \mathrm{bp}$ region conserved in L. luteus ENOD40-1 and ENOD40-2 located directly upstream of the ENOD40-1 putative transcription start site. The ACTA element, a 10-nucleotide motif proximal to the transcription start site with the consensus sequence of TTC(T/C)CCACTA, is also present in the ENOD40 genes of Papilionoideae and Poaceae. Putative TATA boxes in the conserved region are $40 \mathrm{bp}$ upstream of the ACTA element. Promoters of both genes have regions highly similar to distinct regions of G. max ENOD40-2 promoter, located several hundred base pairs upstream of the ACTA element, and inverted (ENOD40-1) or direct (ENOD40-2) repeats situated around $1.5 \mathrm{~kb}$ above the ACTA element.

The ENOD40-1 and ENOD40-2 cDNA probes hybridized to two genomic DNA fragments: a long- 


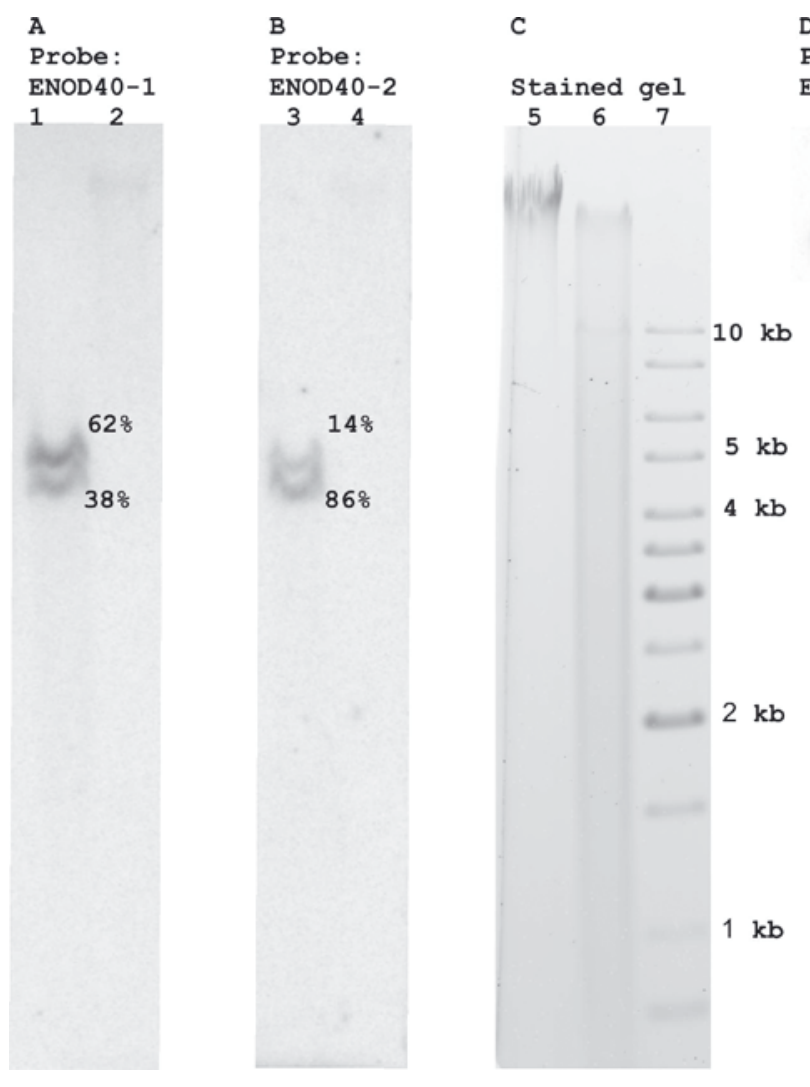

er fragment $(4.6 \mathrm{~kb})$ that hybridized more efficiently with the ENOD40-1 probe, and a shorter one $(4.0 \mathrm{~kb})$ that hybridized more intensely with the ENOD40-2 probe (Fig. 1). Attempts of Southern analysis of genomic DNA with ENOD40-1 and ENOD40-2 specific fragments were unsuccessful, most likely due to the length of the fragments (49 bp and $121 \mathrm{bp}$ ), which did not support efficient hybridization. Hybridization with the short ENOD40-1 specific fragment produced a signal forty times less intense than the fulllength ENOD40-1 cDNA (Fig. 1D). Hybridization of the same amount (50 ng) of both cDNAs with the whole cDNA of ENOD40-1 (Fig. 1D) and ENOD402 (not shown) proved their cross-hybridization and revealed differences between the efficiency of hybridization and cross-hybridization (Fig. 1D). The Southern hybridization results, together with control of the efficiency of cDNAs cross-hybridization, suggest that there are only two genes of high nucleotide similarity to ENOD40-1 and ENOD40-2 in the L. luteus genome.

\section{ENOD40 phylogeny clusters L. luteus genes with genes of plants with determinate nodules}

We analyzed the phylogenetic relationships between L. luteus ENOD40-1 and ENOD40-2 cDNA sequences and 21 legume ENOD40 homologues (accession numbers in Table 1). The L. luteus genes ENOD40-1 and ENOD40-2 are paralogs clustered
Probe: ENOD40-1 $\begin{array}{llll}8 & 9 & 10 & 11\end{array}$

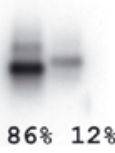

28 68128

(n)

Figure 1. Southern analysis of Lupinus $l u$ teus ENOD40-1 and ENOD40-2 genes.

Five micrograms of genomic DNA was loaded per lane, transferred to a membrane, and the membrane was hybridized with the ENOD40 cDNA probe at $68^{\circ} \mathrm{C}$ (high stringency conditions). The distribution of radioactive probe between the bands on each blot is shown as percentage. A. Genomic DNA was digested with EcoRV and HindIII (lane 1) and the complete cDNA of ENOD40-1 was used as a probe. Undigested genomic DNA was run in lane 2. B. Genomic DNA was digested with EcoRV and HindIII (lane 3) and the complete cDNA of ENOD40-2 was used as a probe. Lane 4 contained undigested genomic DNA. C. The ethidium bromide stained gel of undigested genomic DNA (lane 5), genomic DNA digested with EcoRV and HindIII (lane 6), and $100 \mathrm{ng}$ of the $1 \mathrm{~kb}$ Fermentas marker (lane 7). D. The complete cDNA of ENOD40-1 was used as a probe against the most specific region of ENOD40-1 ( $3^{\prime}$ end fragment of CDNA; 50 ng, lane 8), the most specific region of ENOD40-2 ( $3^{\prime}$ end fragment of cDNA; $50 \mathrm{ng}$, lane 9), the complete ENOD40-1 cDNA (50 ng, lane 10 ), and the complete ENOD40-2 cDNA (50 ng, lane 11).

within group I (plants forming determinate nodules), based on transcriptional unit phylogeny (Fig. 2). The position of the L. luteus genes within group I is not clear, but, importantly, the results indicate that the L. luteus genes are clustered with genes from plants with determinate nodules and are distinct from group II (genes from plants with indeterminate nodules), whereas L. luteus nodules are of persistent meristem. The specificity of Lupinus nodules, in which persistent meristem seems to be of different origin than that of plants from group II, such as Medicago, Pisum or Trifolium, supports the ENOD40 phylogeny (Golinowski et al., 1987, Lotocka et al., 2000; González-Sama et al., 2004; Strozycki et al., 2007). In addition, ENOD40 of Sesbania rostrata, a plant showing intermediate type of nodules, is clustered within group I (Ndoye et al., 1994; Goormachtig et al., 1997).

The ORF A and ORF B peptides from the ENOD40 genes reveal similarities in amino-acid sequence and length within the clusters obtained from the ENOD40 transcriptional unit phylogeny (Table 1). Also, the higher diversity of group I compared to group II is demonstrated by peptide A and $B$ analysis (Table 1) as well as transcriptional unit phylogeny (Fig. 2). The distant position of T. repens ENOD40-3 and M. truncatula ENOD40-2 is well established by both peptide comparison and gene phylogeny. The nucleotide diversity of the two genes opens the possibility that similar ENOD40 genes may be also present in other legume plants. 
Table 1. Papilionoideae ENOD40 peptides A and B.

ENOD40 peptides encoded by two conserved ORFs A and B are clustered according to phylogeny of transcriptional units (Fig. 2) and reveal similarities within the clusters. L. luteus peptides are clustered with peptides from Papilionoideae of determinated nodules (group I), although the lupin nodule is of the indeterminate type. T. repens ENOD40-3 and M. truncatula ENDO40-2 are distinct from groups I and II. Note that conservation of the first three amino acids of ORF B is a result of the two ORFs overlapping.

\begin{tabular}{|c|c|c|}
\hline \multicolumn{3}{|c|}{ Group I, plants with determinate nodules } \\
\hline Accession number, organism, clone & ORF A peptide of 12 amino acids & $\begin{array}{l}\text { ORF B peptide of } 4,5,8,10,11,24,30 \text { amino } \\
\text { acids }\end{array}$ \\
\hline X69154, G. $\max$, ENOD40-1 & MELCWLTTIHGS & MVLEEAWRERGVRGEGAHSSHSLT \\
\hline X86442, G. $\max$, ENOD40-2 & MELCWLTTIHGS & MVLEEAWRERGVRGEGAHSSHSLT \\
\hline D13504, G. $\max , \mathrm{GmN} 36 \mathrm{~b}$ & MELCWLTTIHGS & MVLEEAWRERGVRGEGAHSSHSLT \\
\hline D13503, G. max, GmN36a & MELCWQTSIHGS & MVLEEAWR \\
\hline X86441, Ph. vulgaris, ENOD40 & MKFCWQAS I HGS & MVLKKHGEKGV \\
\hline AF061818, $V$. radiata, ENOD40 & No seq. & No seq. \\
\hline Y12714, S. rostrata, ENOD40 & MKLCWQKS I HGS & MVLKETWEEV \\
\hline AF013594, L. japonicus, ENOD40 & MRFCWQKS I HGS & MALEEAWRGMCERVRVFHPSHT ILCILQFV \\
\hline AJ271788, L. japonicus, ENOD40-2 & MRFCWQKS IHGS & MALEEAWRGMCERVRVFHPSHTLLCILQFV \\
\hline AJ271787, L. japonicus, ENOD40-1 & MKLCWQISIHGS & MVLK \\
\hline AF352375, L. luteus, ENOD40-1 & MELSWQKS IHGS & MVLE \\
\hline AF352374, L. luteus, ENOD40-2 & MKLFWQKSINGS & MVLDS \\
\hline \multicolumn{3}{|c|}{ Group II, plants with indeterminate nodules } \\
\hline Accession number, organism, clone & ORF A peptide of 13 amino acids & ORF B peptide of 14,15 amino acids \\
\hline AJ000268, T. repens, ENOD40 & MKLLCWQKSIHGS & MVLKTNMERSVRGLY \\
\hline AF426839, T. repens, ENOD40-2 & MKLLCWQKS IHGS & MVLKTNMERSVRGLY \\
\hline AF426838, T. repens, ENOD40-1 & MKLLCWQKS IHGS & MVLKTNMERSVRGLY \\
\hline X83683, V. sativa, ENOD40 & MKLLCWQKS IHGS & MVLKIKHGEKCERVN \\
\hline X81064, P. sativum, ENOD40 & MKFLCWQKS IHGS & MVLKNKYGVKCERAN \\
\hline L32806, M. sativa, ENOD40 & MKLLCWQKSIHGS & MVLKTNMERSVRGY \\
\hline X80263, M. sativa, ENOD40 & MKLLCWQKS IHGS & MVLKTNMERSVRGY \\
\hline X80264, M. truncatula, ENOD40 & MKLLCWEKS IHGS & MVLKTNMERSVRGY \\
\hline X80262, M. truncatula, ENOD40 & MKLLCWQKS IHGS & MVLKTNMERSVRGY \\
\hline \multicolumn{3}{|l|}{ Distant ENOD40 genes } \\
\hline Accession number, organism, clone & $\begin{array}{l}\text { ORF A peptide of } 11,12 \text { amino } \\
\text { acids }\end{array}$ & ORF B peptide of 8,28 amino acids \\
\hline AF426840, T. repens, ENOD40-3 & MDLCWQKSIHGS & MVLKGRMEKLCERVLTMTLHTLHLQQFA \\
\hline $\begin{array}{l}\text { M. truncatula ENOD40-2 } \\
\text { (Wan et al., 2007) }\end{array}$ & MNLCWQKS IYD & \\
\hline
\end{tabular}

Analysis of the 23 legume ENOD40 sequences for conserved regions identified eight motifs (position in bp according to L. luteus ENOD40-1): motif 51-91 corresponds to conserved region I, motif 150157 at the basis of domain 2, motif 172-181 within domain 2, motifs 282-312 and 330-335 within conserved region II, and motifs 424-433, 447-464 and 480-493 within domain 6. Each of the motifs has more than $60 \%$ conserved positions (occupied by the same nucleotide) when analysed within group I or group II. The most conserved motifs are the short motif 150-157, of eight out of nine positions conserved in genes from both groups I and II, and motif 330-335 of all six residues conserved in all legume ENOD40 genes except for those from S. rostrata. A function may be assigned to some of the motifs based on the transcript structure: domain 2 depends on interactions of motifs 150-157 and 172-181 with the conserved region II, similarly, motif 447-464 interacts with motif $480-493$ to form domain 6 . The role of the other motifs is not yet clear, but they may be useful for the transcript secondary structure validation.

ENOD40-1 is only expressed in symbiotic root nodules whereas ENOD40-2 is also expressed in nonsymbiotic organs

Northern hybridization analyses showed that L. luteus ENOD40 genes were expressed at early stages of symbiosis starting from the third day postinfection (3 DPI) with Bradyrhizobium sp. until 14 DPI, the oldest tested stage of symbiosis. The highest level of ENOD40 transcripts was found in the mature nodules at 14 DPI (Fig. 3A-C). A decrease of ENOD40 gene expression was observed between the third and eighth day after infection. As the Northern technique could not distinguish the two L. luteus ENOD40 genes due to cross-hybridization of the probes (see Fig. 1D), the expression pattern of ENOD40 genes was confirmed by reverse transcription followed by PCR amplification, in which 


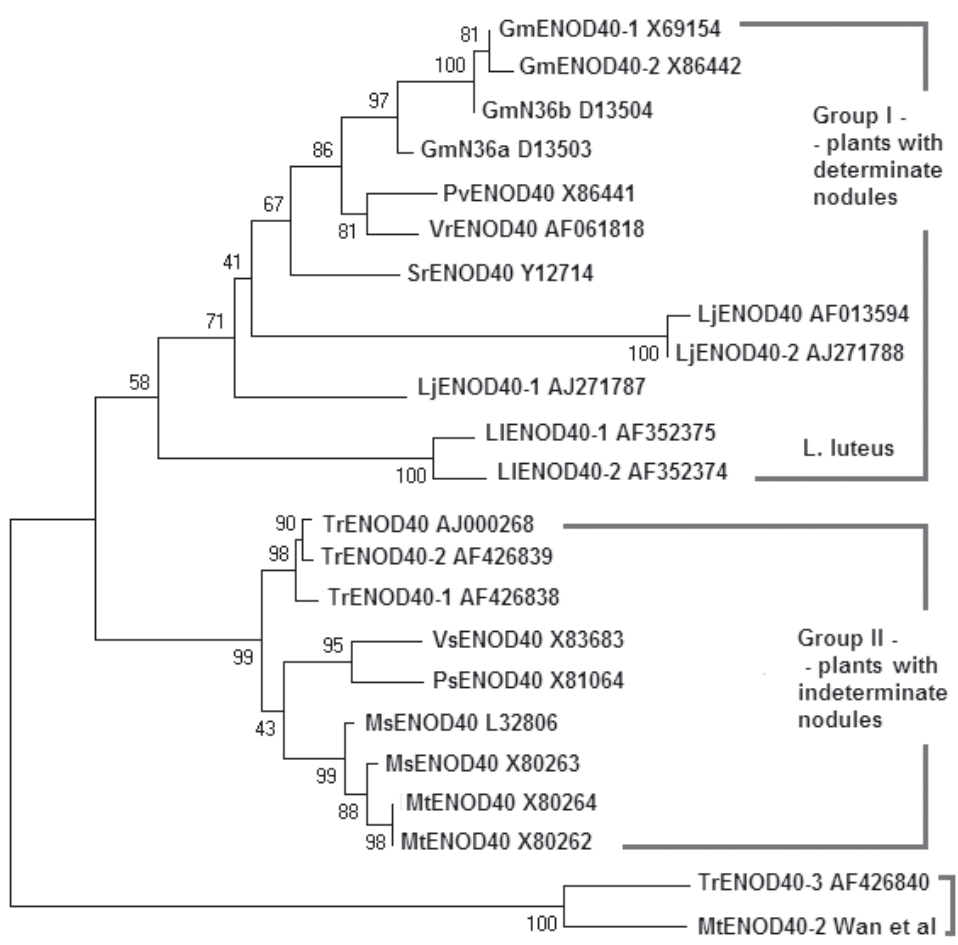

$\stackrel{\vdash}{0.05}$
Figure 2. Evolutionary relationships of ENOD40 genes.

The evolutionary history of ENOD40 genes was inferred using the NeighborJoining method. The optimal tree with a branch length of 1.92971421 is shown. The percentages of replicate trees in which the associated taxa cluster together in the bootstrap test (500 replicates) are shown next to the branches. The tree is drawn to scale with branch length in units of the number of base substitution per site. L. luteus ENOD401 and ENOD40-2 are clustered within group I, plants of determinate nodules, similar to $S$. rostrata ENOD40. The genes are labeled with accession numbers and abbreviations: Mt, M. truncatula; Ms, M. sativa; Tr, T. repens; Vs, V. sativa; Ps, $P$. satioum; Lj, L. japonicus; Ll, L. luteus; Sr, S. rostrata; Gm, G. max; Pv, P. vulgaris; $\mathrm{Vr}, V$. radiata; the list of the full names of the genes with species and accession numbers is given in Table 1. gene-specific primers allowed the specific analysis of ENOD40-1 and ENOD40-2 (Fig. 3D-F). The results showed that both genes exhibited the same expression pattern during development of the symbiotic organ. The higher sensitivity of RT-PCR allowed the detection of very low levels of ENOD40-2 transcripts in uninfected roots at 14 DPI and in root tips (Fig. 3E). Notably, ENOD40-1 transcripts were not detected in uninfected roots or in shoot tips, thus expression in non-symbiotic organs differentiated the L. luteus ENOD40 genes.

Reporter gene fused to ENOD40-1 ORF A and B, but not to the longest ORF, is translated

The translation of ENOD40-1 ORF A (start codon at position 51) that encodes the 12 amino-acid peptide A, ORF B (start codon at position 79) that encodes the 4 amino-acid peptide B, and ORF 330, the longest ORF of 25 codons (start codon at position 330) was tested in $N$. tabacum leaves using a transient expression assay. ORF A and ORF B are the two first ORFs of L. luteus ENOD40-1 with start codons in different reading frames; ORF 330 is not only the longest ORF of ENDO40-1, but its start codon is located in motif 330-335, which is conserved in all legume ENOD40 genes apart from S. rostrata. The experimental constructs contained the specific ENOD40-1 fragments fused to an ATG-less GUS coding sequence under the control of the CaMV $35 \mathrm{~S}$ promoter. Removing the start codon from the reporter gene coding sequence eliminated potential false positive results, as the observed GUS activity was proof of translation starting from the ORF, and not GUS, start codon.

The results demonstrated high expression of ORF A, with efficiency depending on the $5^{\prime}$ UTR (Fig. 4A, B). The construct including the short ORF B showed much lower expression (Fig. 4C). No expression of ORF 330 was observed under these experimental conditions (Fig. 4D). Of the three analyzed ORFs, ORF A starting codon is in a context (length of the upstream region, sequence composition in the vicinity of the codon, structural elements, etc.) promoting efficient initiation of translation. Also, the relationship between the $5^{\prime}$ UTR and translation efficiency suggests that ORF A serves as a template for peptide synthesis in the native ENOD40-1 mRNA molecule.

\section{The secondary structure of the ENOD40-1 transcript}

The secondary structure of the ENOD40-1 RNA was analyzed using $\mathrm{Pb}(\mathrm{II})$-induced cleavage. This method is well suited for probing RNA structure, as $\mathrm{Pb}$ (II) ions preferentially induce RNA chain breakages in single-stranded regions of high flexibility (Ciesiolka et al., 1998). The location of all $\mathrm{Pb}(\mathrm{II})$ induced cleavage sites within the ENOD40-1 transcript is displayed in Fig. 5, and the radiogram of region 165-290 (domain 2) is shown in Fig. 6. Apart from many observed weak cleavages, three strongly 

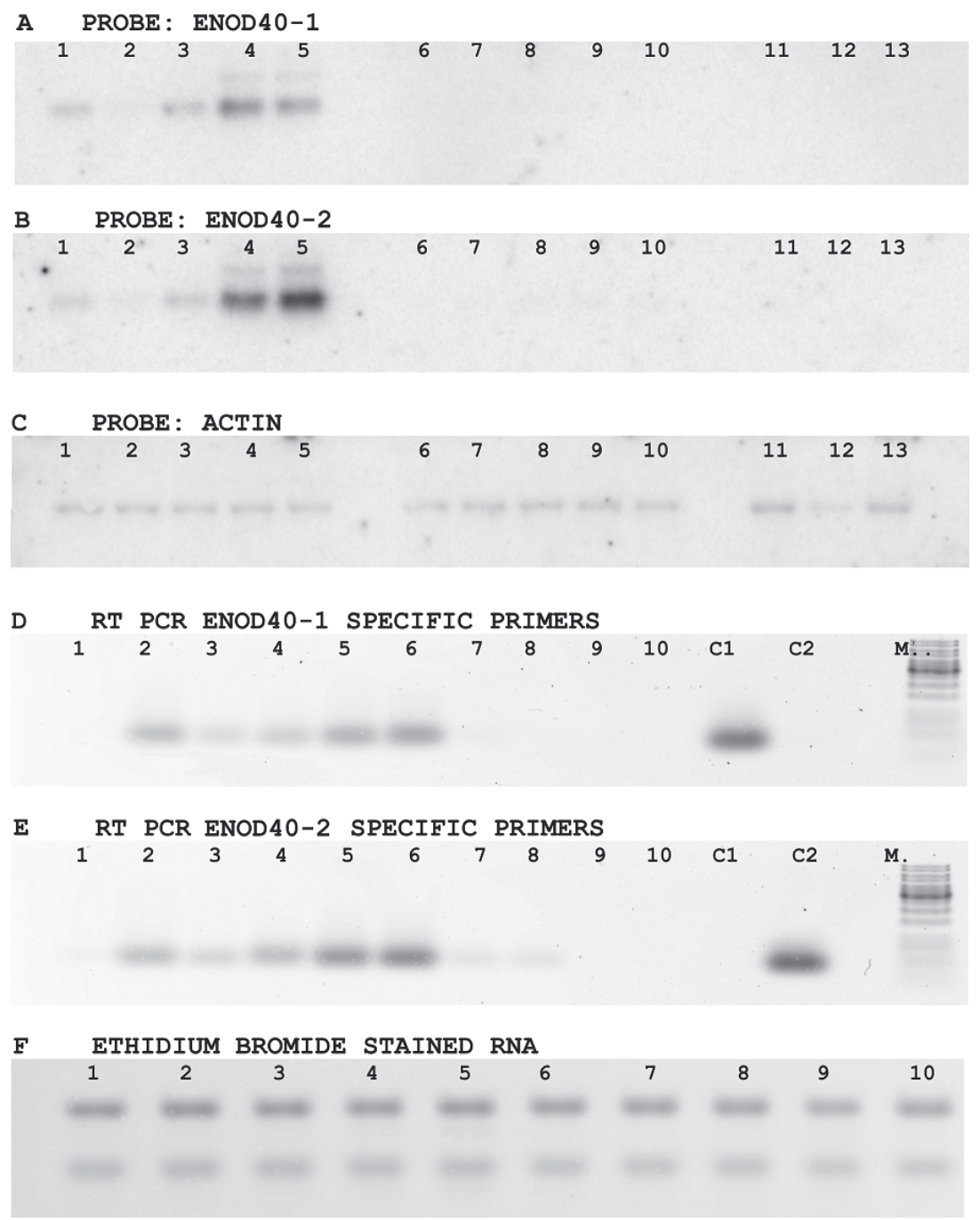

Figure 3. Expression of L. luteus ENOD40-1 and ENOD40-2.

Panels A, B and C show Northern hybridization with $5 \mu \mathrm{g}$ of total RNA per lane: lane 1, infected plant 3 DPI; lane 2, infected plant 5 DPI; lane 3, infected plant 8 DPI; lane 4 , infected plant 11 DPI; lane 5, infected plant 14 DPI; lane 6, uninfected plant 3 DPI; lane 7, uninfected plant 5 DPI; lane 8, uninfected plant 8 DPI; lane 9, uninfected plant 11 DPI; lane 10, uninfected plant 14 DPI; lane 11, root tip $(0.5 \mathrm{~cm})$; lane 12 , shoot tip $(0.5 \mathrm{~cm})$; and lane 13 , inflorescence. The complete cDNA of ENOD40-1 and ENOD40-2 was used as a probe in $\mathrm{A}$ and $\mathrm{B}$, respectively; hybridization with actin (C) confirmed equal loading of RNA samples. (D-F) RT-PCR analysis of ENOD40-1 and ENOD40-2 expression with gene-specific primers for ENOD40-1 (D) and ENOD40-2 (E); lane 1, uninfected plant 3 DPI; lane 2, infected plant 3 DPI; lane 3, infected plant 5 DPI; lane 4 , infected plant 8 DPI; lane 5, infected plant 11 DPI; lane 6, infected plant 14 DPI; lane 7, uninfected plant 14 DPI; lane 8 , root tip $(0.5 \mathrm{~cm})$; lane 9 , shoot tip $(0.5 \mathrm{~cm})$; lane 10 , inflorescence; lane C1, $0.05 \mathrm{ng}$ of ENOD40-1 cDNA as PCR template; lane C2, $0.05 \mathrm{ng}$ of ENOD40-2 cDNA as PCR template; lane M, 1 kb Fermentas marker, 100 ng. (F) Equal RNA amount used for reverse transcription was confirmed by ethidium bromide staining; lanes 1 to 10 as on Fig. 3D and E, with $0.5 \mu \mathrm{g}$ of RNA per lane. cleaved sites are located within domain 2 at positions C188, G255 and C256 (Fig. 6). Such efficient and highly specific cleavages often occur at strong $\mathrm{Pb}$ (II) binding sites, such as, for example, in yeast tRNA $^{\text {Phe }}$ (Ciesiolka et al., 1998). Other metal ions, including $\mathrm{Mg}(\mathrm{II})$, may occupy the same binding sites and are displaced by $\mathrm{Pb}$ (II) under experimental conditions (Kirsebom \& Ciesiolka, 2005). Thus, we suggest that domain 2 of ENOD40-1 contains the main metal ion binding sites, which also includes structural $\mathrm{Mg}(\mathrm{II})$ ions.

The modeling of the ENOD40-1 structure with fixed domains 1, 2, 3, and 6 (Girard et al., 2003) yielded nine models of free energy ranging from -114.95 to $-122.54 \mathrm{kcal} / \mathrm{mol}$.

Domain 5 was not present in any of these models. The models were scored according to the following criteria: number of $\mathrm{Pb}(\mathrm{II})$-induced cleavage sites in double stranded regions without cleavage on the complementary strand (exclusively regions outside the domains) and number of paired nucleotides in regions A35-U40, G88-G94, U376-G381 and
U399-A410 corresponding to G. $\max$ ENOD40-1 single-stranded regions (Girard et al., 2003). The model with the lowest number of nucleotides matching the above criteria had a dG of $-118.34 \mathrm{kcal} / \mathrm{mol}$ (Fig. 7). The distribution of nucleotides accessible to $\mathrm{Pb}(\mathrm{II})$ digestion within domains revealed single stranded regions, bulges or regions of weak structure. Domains 3 and 6 with stable stems and loops or bulges accessible to $\mathrm{Pb}(\mathrm{II})$ ion digestion provide the best evidence of the correspondence between $\mathrm{Pb}$ (II) ion digestion results and the computational folding of RNA. The stem-loop structure in region 371-420 between domains 3 and 6 is weak, likely due to a large internal loop. The efficient $\mathrm{Pb}(\mathrm{II})$-induced digestion of this region is in agreement with G. $\max$ ENOD40-1 data, as the structure contains two partially single stranded regions (376-381 and 399-410) corresponding to the single stranded regions of G. max ENOD40-1 (332-337 and 355-366) (Girard et al., 2003).

The global folding of the L. luteus ENOD40-1 RNA model involves long distance interactions be- 


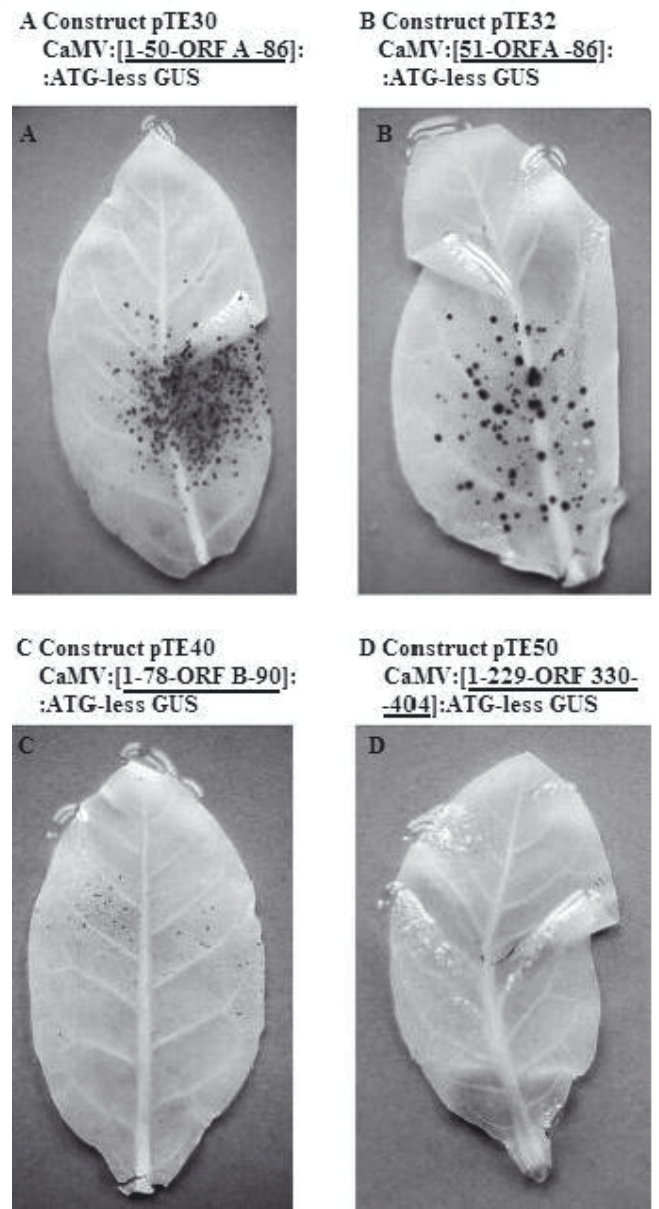

Figure 4. Translational activity of ENOD40-1 ORFs in N. tabacum leaves.

The translational activity of ENOD40-1 ORF A, ORF B, A and ORF 330 (see Fig. 6) was analyzed with a transient expression assay; the constructs pTE30-pTE50 are composed of ENOD40-1 fragment with the analyzed ORF fused in frame with ATG-less GUS under the control of the 35S CaMV promoter. A. Expression of the pTE30 construct with ENOD40-1 fragment 1-86 bp (ORF A with 5' UTR). B. the pTE32 construct with ENOD40-1 fragment 51-86 bp (ORF A without 5' UTR). C. the pTE40 construct with ENOD40-1 fragment 1-90 bp (ORF B with the upstream region); and D. the pTE50 construct with the ENOD40-1 fragment 1-404 (ORF 330 with the upstream region); the ENOD40 fragments are underlined in brackets.

tween the conserved region I and region situated between domains 3 and 6 . This interface between conserved region I and the distal part of the L. luteus ENOD40-1 RNA molecule is rich in nucleotides resistant to $\mathrm{Pb}(\mathrm{II})$-induced cleavage and self-degradation: G64-G, U80-G-G, A93-G, G306-C, A343-U-G-G, and $\mathrm{C} 425-\mathrm{C}$. Such nucleotides are characteristic for double stranded, stable regions of strong structure, such as stem base. The $330-335$ region is a unique single stranded region composed of nucleotides resistant to digestion, which suggests that the motif might be involved in long distance interactions responsible for the transcript tertiary structure forma- tion. The high conservancy of motif 330-335 reinforces such hypothesis. Also, pairing between conserved region I and one of the motifs conserved in legume ENOD40 genes (motif 424-432) supports the L. luteus ENOD40-1 model, which shows the conserved region I interacting with a region upstream of domain 6 .

\section{DISCUSSION}

Here we present an analysis of the $L$. luteus ENOD40 genes including expression patterns, translational capability and RNA secondary structures. Detailed analysis of L. luteus ENOD40 genes has revealed regions within the promoters to be structurally similar to the G. max ENOD40-2 promoter, repeats and $89 \mathrm{bp}$ conserved fragment just upstream of the transcription start site. The conservation of this region upstream of the transcription start site correlates with the phylogeny of the ENOD40 transcriptional units; even evolutionarily distant ENOD40 genes, like the genes from L. luteus and M. truncatula or M. sativa, showed $85 \%$ identity within the $41 \mathrm{bp}$ regions upstream of the ACTA element. The ACTA element and upstream conserved region are present in the 185-bp G. max ENOD40-2 minimal promoter, which is sufficient for expression under symbiotic conditions (Gronlund et al., 2005), supporting the hypothesis regarding the functional importance of these elements. The function of the $10 \mathrm{nt}$ ACTA element, which is present in the promoters of Papilionideae and Poaceae ENOD40 genes, may be associated with transcription start recognition.

The pattern and expression level of both genes are similar during symbiosis, with the highest expression detected in mature nodules. The decrease of expression between 3 and 8 DPI might be associated with abortion of nodule primordia observed at approx. 5 DPI (Lotocka et al., 2000). The low level of LlENOD40-2 transcripts detected in uninfected roots and root tips is similar to the expression patterns of M. sativa ENOD40-1 and ENOD40-2 (Fang \& Hirsch, 1998) and S. rostrata (Corich et al., 1998).

The high efficiency of ENOD40-1 ORF A translation indicates that the ORF A starting codon is in a context (sequence composition, position regard mRNA 5' end, structural elements) promoting initiation of peptide synthesis. The ORF B fusion with reporter gene exhibited lower levels of expression, and in the native ENOD40 transcript the ORF B mRNA may not be translated due to the mRNA structure. The start codon of ORF 330, the longest LIENOD40-1 ORF, is located within the highly conserved motif 330-335 and is not active for translation initiation. The conservation of the motif might 


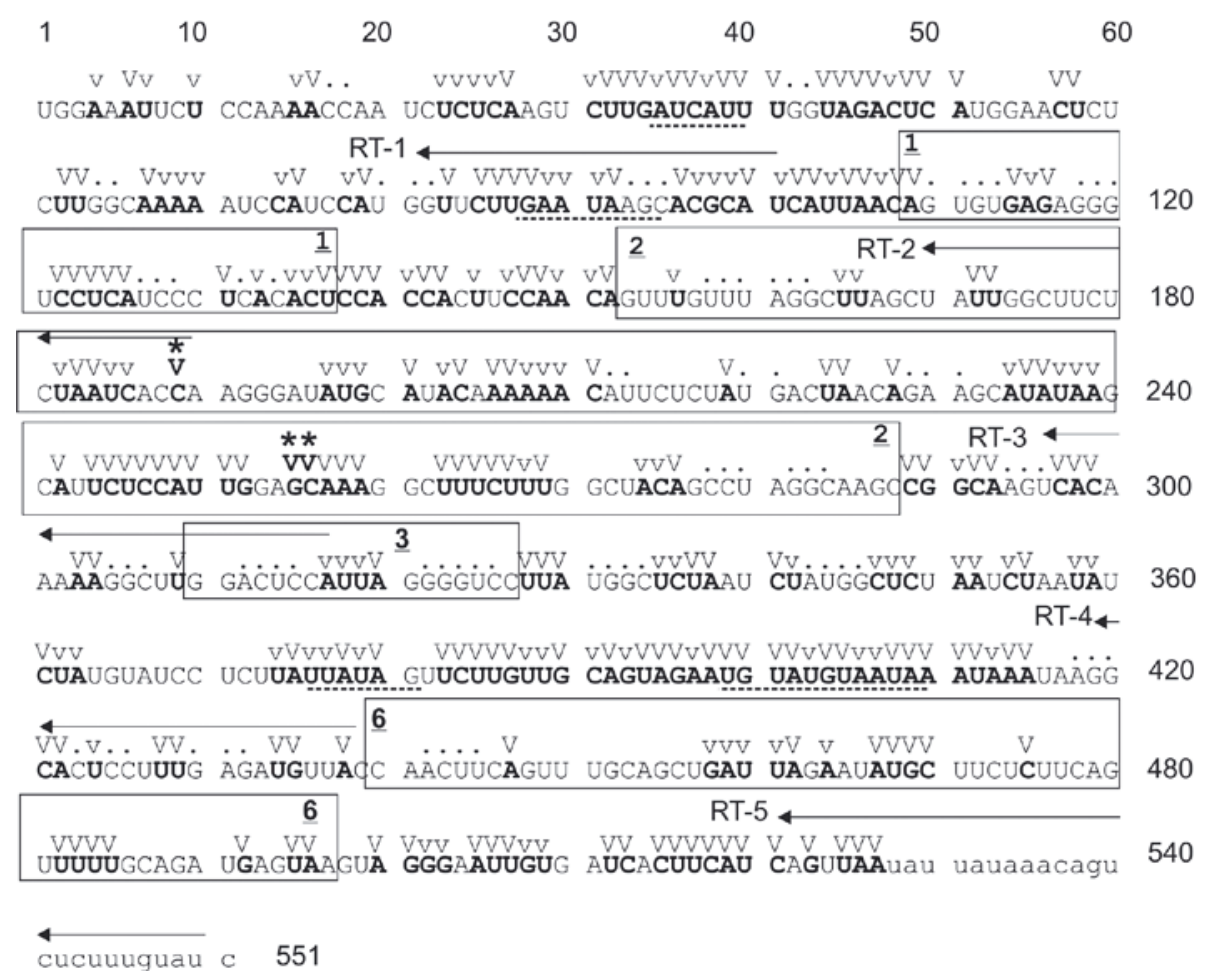

Figure 5. Identification of $\mathrm{Pb}(\mathrm{II})$-induced cleavage sites in L. luteus ENOD40-1 transcript.

The results of ENOD40-1 transcript digestion with $\mathrm{Pb}(\mathrm{II})$ ions are shown; the nucleotides accessible to $\mathrm{Pb}(\mathrm{II})$-induced cleavage are bolded, additionally the major and the minors cuts are marked with " $\mathrm{V}$ " and " $\mathrm{v}$ ", respectively, on the top of the cleaved nucleotide, the regions resistant to $\mathrm{Pb}(\mathrm{II})$-induced cleavage and self-degradation are marked with dots ( $\cdots$.$) .).$ The most efficiently cleaved nucleotides, C188, G255 and C256, are marked with $\mathrm{V}^{*}$. The domains of conserved structure, 1, 2, 3, and 6, are marked in a box, and the regions corresponding to single stranded regions of G. max ENOD40-1 (Girard et al., 2003) are underlined with dashed line (---). The reverse transcriptase primers are shown as arrows labeled RT-1-RT-5. The last 24 nucleotides of the 3 ' end of the transcript, unavailable to $\mathrm{Pb}$ (II) probing, are shown as lower case letters.

be a result of interactions between distant regions of mRNA molecule during folding, as this motif is not accessible to $\mathrm{Pb}$ (II)-induced cleavage.

Phylogenetic analysis revealed that the divergence between lupine ENOD40 genes occurred after speciation. The phylogenetic tree of ENOD40 genes differs from the legume plant phylogeny with regard to the position of L. luteus. Genus Lupinus, a member of the genistoid group that diverged early from other Papilionideae, is well separated from two other younger clades: the hologalegina group (including Lotus, Sesbania, Medicago, Pisum, Vicia and Trifolium), and the phaseoloidmillettioid group that includes Glycine, Phasoleus and Vigna (Doyle \& Luckow, 2003). The clustering of the L. luteus ENOD40 genes with the Lotus and Glycine genes may be linked to the specificity of nodule development within the genus Lupinus. $\mathrm{Lu}$ pinus nodules have a persistent meristem but nodules formed from outer cortical cells, absence of infection threads and infected meristematic cells make this plant distinct from the other legume plants forming indeterminate nodules (Lotocka et al., 2000; González-Sama et al., 2004; Strozycki et al., 2007).
The distant phylogenetic position of $T$. repens ENOD40-3 and M. truncatula ENOD40-2 genes indicate that such genes might be also present in other legumes, including L. luteus, as the hybridization and RT-PCR techniques are unable to detect genes of low nucleotide similarity.

The similarities of peptide A and B within the clusters obtained from the phylogenetic analysis of ENOD40 transcriptional unit suggest that the region containing SORFs for the two peptides is under selection pressure. The amino acid substitutions in the second position of peptide $A(K>E>R>D, N)$ follows the rules for solvent exposed amino acids, reinforcing the hypothesis of ORF A translation.

A model of LIENOD40-1 transcript secondary structure was selected from nine models using data from the $\mathrm{Pb}(\mathrm{II})$-induced cleavage, a method applied for solving the secondary structure of many tRNAs, $5 S$ rRNA, $16 \mathrm{~S}$ rRNA and ribozymes (Kirsebom \& Ciesiolka, 2005). The minor differences between the G. max and L. luteus ENOD40 models might be a result of the probe size, as lead ions are much smaller than enzymes and some RNA regions accessible to $\mathrm{Pb}(\mathrm{II})$ induced cleavages are not available for enzyme digestion. The L. luteus ENOD40 model validation is based 


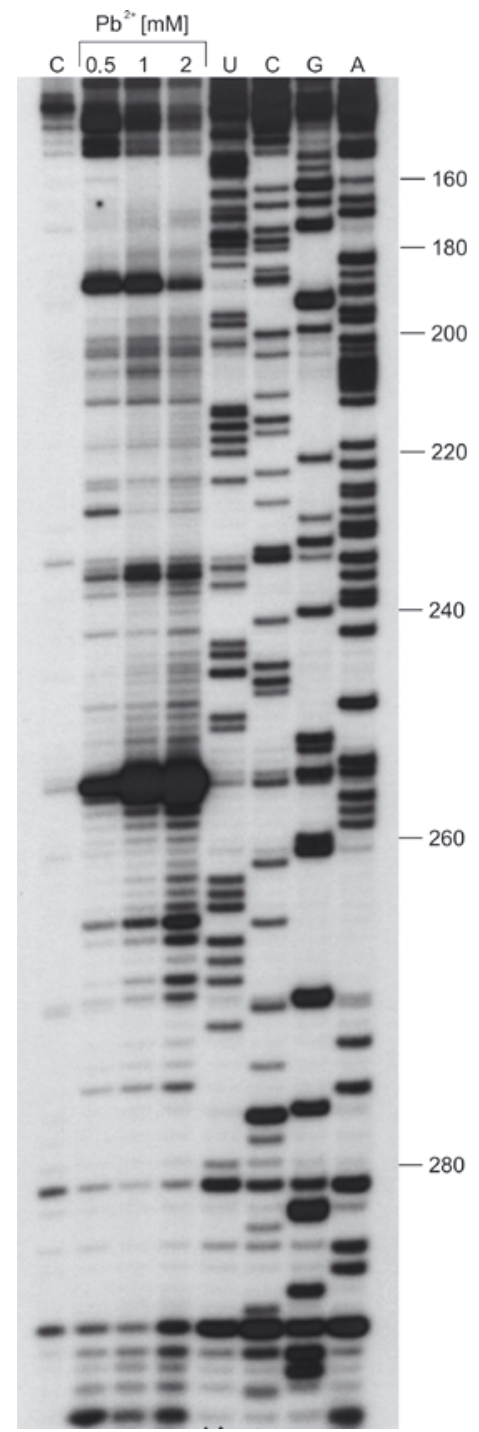

Figure 6. Autoradiogram of $\mathrm{Pb}(\mathrm{II})$-induced cleavage sites in the ENOD40-1 transcript, region 160-293.

The autoradiogram shows products of $\mathrm{Pb}$ (II) cleavage reaction copied on cDNA with reverse transcription primer RT-3 and run along with dideoxy sequencing reactions on $12 \%$ polyacrylamide gel; the region $160-293$ spanning almost the entire domain 2 contains C188, G255 and C256, the most efficiently cleaved nucleotides. The numbers of positions given on the left of the gel are according to the sequence presented in Figs. 5 and 7. Lane $C$ shows the control without treatment with $\mathrm{Pb}(\mathrm{II})$. Lanes marked 0.5, 1 , and $2 \mathrm{mM}$ indicate increasing concentration of $\mathrm{Pb}(\mathrm{II})$ ions; lanes U, C, G, and A indicate sequencing lanes of thymidine, cytidine, guanine and adenine, respectively.

on well-defined single-stranded regions of G. $\max$ ENOD40-1 (Girard et al., 2003). Two of these regions, LIENOD40-1 regions 35-40 and 376-381, are singlestranded and the other two, 88-95 and 399-410 are partially single-stranded with almost all nucleotides, even within the double-stranded structures, accessible to $\mathrm{Pb}$ (II)-induced cleavage, indicating that the structures are weak. The localization of conserved motifs in legume ENOD40 transcripts also supports the pro- posed structure: the 150-157 motif (ACAGUUUG) is positioned opposite a highly conserved motif from the conserved region II at the basis of domain 2, motifs $447-464$ and $480-493$ are located on the opposite strands of domain 6 , and the pairing between motif 58-65 and motif 424-433 is one of the long distance interactions crucial for the LIENOD40-1 transcript folding (Fig. 7). These long distance interactions responsible for organizing the domains within the ENOD40-1 mRNA molecule depend on pairing between regions 52-95 and 306-441. Analysis of 24 nucleotide pairs formed between regions 52-95 and 306-441 revealed ten substitutions between LIENOD40-1 and LIENOD40-2 that do not disrupt the model, and only slightly decrease the number of paired nucleotides from 24 for LIENOD40-1 to 21 for LIENOD40-2.

The most important difference between the LIENOD40-1 and G. max ENOD40-1 models concerns the interactions of conserved region I, especially at its $5^{\prime}$ end. In the case of the G. max ENOD40-1 model, this region forms hairpins, whereas the LIENOD40-1 model proposes pairing of the $5^{\prime}$ end of the conserved region I with region $425-441$ located upstream of domain 6. The G. max ENOD40-1 regions corresponding to paired L. luteus ENOD40-1 regions 51-65 and 425-441 are well conserved and might form a 13-nucleotide double-stranded structure (one more than for $L$. $l u$ teus ENOD40-1), but in G. max ENOD40-1 the region corresponding to L. luteus region 425-441 is involved in the formation of domain 5.

The differences between the $L$. luteus ENOD40-1 and G. max ENOD40-1 models might result from transcript length, as the G. max ENOD40-1 transcript is $107 \mathrm{nt}(19 \%)$ longer then L. luteus ENOD40-1, the shortest legume ENOD40 gene. Another possibility is that ENOD40 transcripts may switch between two structures depending on cellular conditions, and the two models correspond to these two different states. Furthermore, such two states of the ENDO40 mRNA molecule might be associated with different activities of the transcript, either functioning as a template for short peptide synthesis or as an RNA of biological function independent of translation.

\section{Acknowledgements}

We thank B. Dlugaszewska and G. Nimmagada for help with genomic clone isolation and analysis, I. Femiak for assistance with transient expression, and Dr. Z. Michalski for assistance with preparation of the figures.

This work was funded by the State Committee for Scientific Research, grant P04B 020 23, the Ministry of Science and Higher Education - network "Genomics and transgenesis of crop plants" and grant N 519314635. 


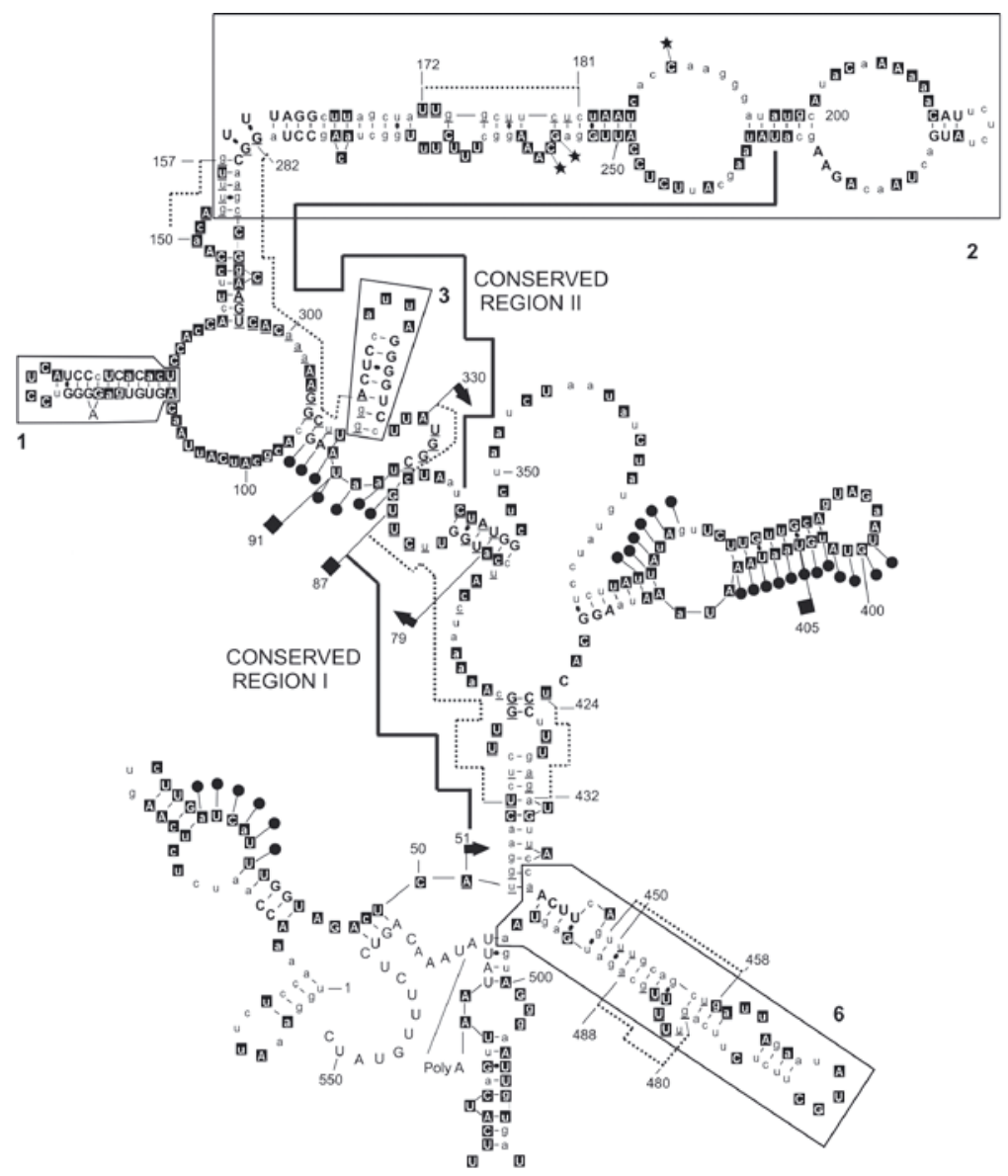

Figure 7. Model of the secondary structure of ENOD40-1 transcript.

The L. luteus ENOD40-1 model is one of nine structures generated with the mfold program and selected as described in the text; the structures of domains 1, 2, 3, and 6 are according to Girard et al. (2003). The features important for the model validation are marked with an asterisk (the most efficiently $\mathrm{Pb}^{2+}$ cleaved nucleotides), capital letters in black squares $\left(\mathrm{Pb}^{2+}\right.$ strongly cleaved nucleotide), small letters in black squares $\left(\mathrm{Pb}^{2+}\right.$ weakly cleaved nucleotide), small letters (uncleaved nucleotide), bold capital letters (nucleotide resistant to $\mathrm{Pb}^{2+}$ cleavage and self degradation (regions of highly stable structure)), black circles (regions corresponding to single stranded regions of G. max ENOD40-1 mRNA (Girard et al., 2003)), black arrows (starting codon of ORFs discussed in the text), black squares (stop codon of the ORFs discussed in the text), rectangles 1, 2, 3, and 6 (domains of conserved structure (Girard et al., 2003)), solid lines (conserved regions I and II), dotted lines (motifs conserved in legume ENOD40 genes (see text)), underlined letters (conserved position), and poly(A) (putative polyadenylation signal).

\section{REFERENCES}

Asad S, Fang Y, Wycoff KL, Hirsch AM (1994) Isolation and characterization of cDNA and genomic clones of MsENOD40; transcripts are detected in meristematic cells of alfalfa. Protoplasma 183: 10-23.

Barciszewski J, Legocki A (1997) Two plant signaling peptides: systemin and ENOD 40. Acta Biochim Polon 44: 795-802.

Campalans A, Kondorosi A, Crespi M (2004) Enod40, a short open reading frame-containing mRNA, induces cytoplasmic localization of a nuclear RNA binding protein in Medicago truncatula. Plant Cell 16: 1047-1059.

Charon C, Johansson C, Kondorosi E, Kondorosi A, Crespi M (1997) enod40 induces dedifferentiation and division of root cortical cells in legumes. Proc Natl Acad Sci USA 94: 8901-8906.

Charon C, Sousa C, Crespi M, Kondorosi A (1999) Alteration of enod40 expression modifies Medicago truncatula root nodule development induced by sinorhizobium meliloti. Plant Cell 11: 1953-1966.

Ciesiolka J, Michalowski D, Wrzesinski J, Krajewski J, Krzyzosiak WJ (1998) Patterns of cleavages induced by lead ions in defined RNA secondary structure motifs. J Mol Biol 275: 211-220.

Compaan B, Ruttink T, Albrecht C, Meeley R, Bisseling T, Franssen H (2003) Identification and characterization of a Zea mays line carrying a transposon-tagged ENOD40. Biochim Biophys Acta 1629: 84-91.

Corich V, Goormachtig S, Lievens S, Van Montagu M, Holsters M (1998) Patterns of ENOD40 gene expression in stem-borne nodules of Sesbania rostrata. Plant Mol Biol 37: $67-76$.
Crespi MD, Jurkevitch E, Poiret M, d'Aubenton-Carafa Y, Petrovics G, Kondorosi E, Kondorosi A (1994) enod40, a gene expressed during nodule organogenesis, codes for a non-translatable RNA involved in plant growth. EMBO J 13: 5099-112.

Dey M, Complainville A, Charon C, Torrizo L, Kondorosi A, Crespi M, Datta S (2004) Phytohormonal responses in enod40-overexpressing plants of Medicago truncatula and rice. Physiol Plant 120: 132-139.

Doyle JJ, Luckow MA (2003) The rest of the iceberg. Legume diversity and evolution in a phylogenetic context. Plant Physiol 131: 900-910.

Fang Y, Hirsch AM (1998) Studying early nodulin gene ENOD40 expression and induction by nodulation factor and cytokinin in transgenic alfalfa. Plant Physiol 116: 53-68.

Felsenstein J (1981) Evolutionary trees from DNA sequences: a maximum likelihood approach. J Mol Evol 17: 368-376.

Girard G, Roussis A, Gultyaev AP, Pleij CW, Spaink HP (2003) Structural motifs in the RNA encoded by the early nodulation gene enod40 of soybean. Nucleic Acids Res 31: 5003-5015.

Golinowski W, Kopcinska J, Borucki W (1987) The morphogenesis of lupine root nodule during infection by Rhizobium lupinii. Acta Soc Bot Pol 56: 687-703.

Gonzalez-Sama A, Lucas MM, de Felipe MR, Pueyo JJ (2004) An unusual infection mechanism and nodule morphogenesis in white lupin (Lupinus albus). New Phytologist 163: 371-380.

Goormachtig S, Alves-Ferreira M, Van Montagu M, Engler G, Holsters M (1997) Expression of cell cycle genes 
during Sesbania rostrata stem nodule development. Mol Plant Microbe Interact 10: 316-325.

Gronlund M, Roussis A, Flemetakis E, Quaedvlieg NE, Schlaman HR, Umehara Y, Katinakis P, Stougaard J, Spaink HP (2005) Analysis of promoter activity of the early nodulin Enod40 in Lotus japonicus. Mol Plant Microbe Interact 18: 414-427.

Gultyaev AP, Roussis A (2007) Identification of conserved secondary structures and expansion segments in enod40 RNAs reveals new enod40 homologues in plants. Nucleic Acids Res 35: 3144-3152.

Guzzo F, Portaluppi P, Grisi R, Barone S, Zampieri S, Franssen H, Levi M (2005) Reduction of cell size induced by enod40 in Arabidopsis thaliana. J Exp Bot 56: 507-13.

Hardin SC, Tang GQ, Scholz A, Holtgraewe D, Winter H, Huber SC (2003) Phosphorylation of sucrose synthase at serine 170: occurrence and possible role as a signal for proteolysis. Plant J 35: 588-603.

Kirsebom LA, Ciesiolka J (2005) Pb(II)-induced cleavage of RNA. In: Handbook of RNA Biochemistry. Hartmann RK, Bindereif A, Schon A, Westhof E, eds, pp 214-228. Wiley VCHGmbH\& $\mathrm{Co}$, KgaA, Wenheim, Germany.

Klimecka M, Muszynska G (2007) Structure and functions of plant calcium-dependent protein kinases. Acta Bioch Polon 54: 219-233.

Kouchi H, Hata S (1993) Isolation and characterization of novel nodulin cDNAs representing genes expressed at early stages of soybean nodule development. Mol Gen Genet 238: 106-119.

Kouchi H, Takane K, So RB, Ladha JK, Reddy PM (1999) Rice ENOD40: isolation and expression analysis in rice and transgenic soybean root nodules. Plant J 18: 121129.

Kumagai H, Kinoshita E, Ridge RW, Kouchi H (2006) RNAi knock-down of ENOD40s leads to significant suppression of nodule formation in Lotus japonicus. Plant Cell Physiol 47: 1102-1111.

Larsen K (2003) Molecular cloning and characterization of a cDNA encoding a ryegrass (Lolium perenne) ENOD40 homologue. J Plant Physiol 160: 675-687.

Linsey K (2001) Plant peptide hormones: The long and the short of it. Curr Biol 11: R741-R743.

Logemann J, Schell J, Willmitzer L (1987) Improved method for the isolation of RNA from plant tissues. Anal Biochem 163: 16-20.

Lotocka B, Kopcińska J, Górecka M, Golinowski W (2000) Formation and abortion of root nodule primordia in Lupinus luteus L. Acta Biol Crac Ser Bot 42: 87-100.

Matvienko M, Van de Sande K, Yang WC, van Kammen A, Bisseling T, Franssen H (1994) Comparison of soybean and pea ENOD40 cDNA clones representing genes expressed during both early and late stages of nodule development. Plant Mol Biol 26: 487-493.

Minami E, Kouchi H, Cohn JR, Ogawa T, Stacey G (1996) Expression of the early nodulin, ENOD40, in soybean roots in response to various lipo-chitin signal molecules. Plant J 10: 23-32.

Murakami Y, Miwa $\mathrm{H}$, Imaizumi-Anraku $\mathrm{H}$, Kouchi $\mathrm{H}$, Downie JA, Kawaguchi M, Kawasaki S (2006) Positional cloning identifies Lotus japonicus NSP2, a putative transcription factor of the GRAS family, required for NIN and ENOD40 gene expression in nodule initiation. DNA Res 13: 255-265.

Ndoye I, de Billy F, Vasse J, Dreyfus B, Truchet G (1994) Root nodulation of Sesbania rostrata. I Bacteriol 176: 1060-1068.

Papadopoulou K, Roussis A, Katinakis P (1996) Phaseolus ENOD40 is involved in symbiotic and non-symbiotic organogenetic processes: expression during nodule and lateral root development. Plant Mol Biol 30: 403-417.

Rohrig H, Schmidt J, Miklashevichs E, Schell J, John M (2002) Soybean ENOD40 encodes two peptides that bind to sucrose synthase. Proc Natl Acad Sci USA 99: 1915-1920.

Rohrig H, John M, Schmidt J (2004) Modification of soybean sucrose synthase by S-thiolation with ENOD40 peptide A. Biochem Biophys Res Commun 325: 864-867.

Ruttink T, Boot K, Kijne J, Bisseling T, Franssen H (2006) ENOD40 affects elongation growth in tobacco Bright Yellow-2 cells by alteration of ethylene biosynthesis kinetics. J Exp Bot 57: 3271-3282.

Saitou N, Nei M (1987) The neighbor-joining method. A new method for reconstructing phylogenetic trees. Mol Biol Evol 4: 406-425.

Sambrok J, Russell DW (2002) Molecular Cloning, a laboratory manual; pp 7.31-7.34. Cold Spring Harbor, New York.

Sousa C, Johansson C, Charon C, Manyani H, Sautter C, Kondorosi A, Crespi M (2001) Translational and structural requirements of the early nodulin gene enod40, a short-open reading frame-containing RNA, for elicitation of a cell-specific growth response in the alfalfa root cortex. Mol Cell Biol 21: 354-366.

Strozycki PM, Skapska A, Szczesniak K, Sobieszczuk E, Briat J-F, Legocki AB (2003) Differential expression and evolutionary analysis of the three ferritin genes in the legume plant Lupinus luteus. Physiol Plantarum 118: 380-389.

Strozycki PM, Szczurek A, Lotocka B, Figlerowicz M, Legocki AB (2007) Ferritins and nodulation in Lupinus luteus: iron management in indeterminate type nodules. J Exp Bot 58: 3145-3153.

Tamura K, Dudley J, Nei M, Kumar S (2007) MEGA4: Molecular evolutionary genetics analysis (MEGA) software version 4.0. Mol Biol Evol 24: 1596-1599.

Varkonyi-Gasic E, White DW (2002) The white clover enod40 gene family. Expression patterns of two types of genes indicate a role in vascular function. Plant Physiol 129: 1107-1118.

Vijn I, Yang WC, Pallisgard N, Ostergaard Jensen E, van Kammen A, Bisseling T (1995) VsENOD5, VsENOD12 and VsENOD40 expression during Rhizobium-induced nodule formation on Vicia sativa roots. Plant Mol Biol 28: 1111-1119.

Vincent JM (1970) A Manual for the Practical Study of RootNodule Bacteria. Blackwell Scientific Publications, London.

Vleghels I, Hontelez J, Ribeiro A, Fransz P, Bisseling T, Franssen H (2003) Expression of ENOD40 during tomato plant development. Planta 218: 42-49.

Wan X, Hontelez J, Lillo A, Guarnerio C, van de Peut D, Fedorova E, Bisseling T, Franssen H (2007) Medicago truncatula ENOD40-1 and ENOD40-2 are both involved in nodule initiation and bacteroid development. J Exp Bot 58: 2033-2041.

Wen J, Lease KA, Walker J (2004) DVL, a novel class of small polypeptides: overexpression alters Arabidopsis development. Plant J 37: 668-677.

Yang WC, Katinakis P, Hendriks P, Smolders A, de Vries F, Spee J, van Kammen A, Bisseling T, Franssen $\mathrm{H}$ (1993) Characterization of GmENOD40, a gene showing novel patterns of cell-specific expression during soybean nodule development. Plant J 3: 573-585.

Zucker M (2003) Mfold web server for nucleic acid folding and hybridization prediction. Nucleic Acids Res 31: 3406-3415. 